\title{
Impact of Language on National Identity: An Analysis from Historical Perspective.
}

\author{
Debojit Dey ${ }^{1}$ \\ ${ }^{I}$ (Department of History, S.K.Roy College, India)
}

\begin{abstract}
The emergence of language as the sole basis of national identity is relatively new phenomenon. It appeared as a force to wreck with only in the post-colonial period in South Asia. This is nowhere more prominent then the new nation of Bangladesh. Bangladesh has transcended the barrier of religion and used language as its unifying force. Bangladesh was the earliest East Pakistan of the state of Pakistan. As is known Pakistan was created to satisfy the political aspiration of the Muslim minorities of India. East Pakistan was an integral part of that Pakistan which was created on the basis of religion. But Bangladesh overcame that religious affiliation and unified the people of East Pakistan on the basis of language to start a liberation struggle which ultimately succeeded in the creation of the new nation state of Bangladesh. Although language has always been an integral part of national identity to marked the beginning of a new era of linguistic nationalism. But Bangladesh was not the single example of the emergence of linguistic nationalism. There were parallel instances where language manifested itself in terms of movement and martyrdom. The two cases we have cited here are of Cachar in Assam and Manbhum in Bihar.
\end{abstract}

Keywords- Bangladesh, Cachar, language, liberation struggle and Manbhum.

\section{Introduction}

During the nationalist struggle the pan-Indian sentiment and anti-colonial ideology played the major role in shaping the concept and idea of Indian nation. Simultaneously there was a parallel movement in the regions which was based on the regional vernacular and resistance dominant nationality oppression. These were described as sub-national movements, regional movement or little nationality movements. Though this movement and their own momentum they remained subsidiary to the anti-colonial movement and never tried to challenge the concept of one nation. The only challenge to the concept of one Indian nation came from religious groups like the Muslims and Sikhs. In fact it was religion which eventually led to the partition of India into two sovereign nations. However, the dominant political organization of India - Indian National Congress did not fail to recognize the importance of language and religion. They promised that after independence Indian regions would be organized on the basis of its vernaculars.

Once India attained independence and the idea of Indian nation state have been implemented, the regions demanded attention to their regions and vernaculars. Various movements began to emerge in different parts of the country where different vernaculars were demanded to be recognized or the region be recognized on the basis of its vernaculars. Language movements cannot be studied in separation from nationality questions. Linguistic nationalism are manifested essentially against repression of mother tongue, right to speech, majoritarianism and cultural hegemony are not new in modern history.

In pre-independent India religion played a very important marker of identity and symbol of political mobilization in the nationalist movements of South Asia; however after independence and partition of the country in 1947 religion temporarily ceased to have predominance and language emerged as the new marker of nationality and pivot of nationalist mobilization. In the cases of Bangladesh, Cacher District of Assam and Manbhum of now Purulia District of West Bengal and Jharkhand Bengali language emerged as the symbol of political movement. In all the cases speaker of Bengali language resisted the imposition of another language on them and fought for the reinstatement of their language to themselves. This is strange because Bengali was one of the most advanced languages of India in terms of its modernization and recorded progress. Although most of the Indo-Aryan languages of India began their journey at the same time, Bengali moved slightly ahead due to the advent of the British in Bengal earlier than other provinces. The nineteenth century 'renaissance' and the early impact of European literary advancement on the Bengali language and culture had accelerated the modernization of Bengali language. From Ishwar Chandra Vidyasagar to Bankim Chandra Chatterjee and Michael Madhusudan Dutta, there were massive endeavour to modernize the Bengali language and literature of making the vernacular make remarkable strides. The emergence of Rabindra Nath Tagore and the award of Nobel Prize for literature to him firmly established the comparative dominance of Bengali language.

However, in the areas outside Bengal where there was substantial Bengali settlement, there was a feeling of persecution among the Bengali speakers. The three regions as mentioned above fall in this category. 
Manbhum, was an erstwhile part of Bengal presidency which was now placed under Bihar and under the dominance Hindi Language after the creation of Bihar state. Although a tribal area, it had a significant presence of Bengali population who practiced their own language and culture. Even the tribal of the area were speakers of Bengali language as their own vernacular was neither the medium of instruction nor was the lingua franca. In other words the myriad tribal speeches had relegated into background under the growing dominance of the Bengali language. East Pakistan was the partitioned half of the Bengal province which was overwhelmingly Bengali speaking. But, under the Pakistani rule there was persecution of the Bengali language and attempts of imposition of Urdu Language on them. The Bengali speakers were not only the overwhelming majority in East Pakistan, they were proud speakers of their vernacular. Even though Urdu was considered the language of Indian Muslims, the Muslims of East Pakistan refused to replace their mother tongue with it and resisted the moves to impose it on them as the medium of instruction. The imposition of Urdu was considered an attempt to persecute their mother tongue and impose the hegemony of alien language on them. Similarly in Assam, Bengalis were the dominant minority and a majority in the Cachar District that consisted of three sub-divisions. Hence the attempt to introduce Assamese language by the Government as the medium of instruction as well as official language was seen by this minority as an attempt to persecute their language and the imposition of an alien tongue on them. It is interesting to note that in all the three cases where mother tongue was perceived to be persecuted and consequently a movement was launched to resist against this persecution. In all the movements the mother tongue did not remain simply a 'Language'. It was deified and feminized in the sense that language was elevated as mother tongue and hence viewed as sacred. Its repression was not simply a persecution of a language but the persecution of the mother herself. This mother is the mother of a collectively called nationality. Similarly the death that occurred during the nationalist agitation was not simply death, but martyrdom. Although for the state it was simply a law and problem, for the communities involved in it was a nationalist struggle. A language movement had thus appropriated the nationalist discourse where one nation was shown as the oppressor nation while the other was the oppressed. Language movements had therefore become a part of the collective struggle for national identity and nation building. Let us now analysis the concept of mother tongue and martyrdom as was used in the above mentioned movements.

\section{Concept of Mother Tongue and Martyrdom}

According to the Concise Oxford Dictionary mother tongue means one's native language or language from which others spring. ${ }^{\mathrm{i}}$ The term mother tongue or mother language is used for the language that a person learnt as a child at home (usually from their parents). ${ }^{\text {ii }}$ According to this definition children who grow up in bilingual homes could have more than one mother tongue or native language. The population Census of Canada, Statistics Canada defined mother tongue as "the first language learned at home in childhood and still understood by the individual at the time of the census. "iii It implies therefore that it is quite possible that the first language learned was no longer a speaker's dominant language. This included young immigrant children, whose families have moved to a new linguistic environment, as well as people who learned their mother tongue as a young child at home (rather than the language of the majority of the community), who may have lost, in part or in totality, the language they first acquired. ${ }^{\text {iv }}$

Mother tongue is a concept. The origin of the concept of "mother tongue" can be traced to the notion that the first speech of the child is actually learnt from his mother by the child and as such his/her linguistic skills of a child are honed by the mother and therefore the language spoken by the mother would be the primary language that the child would learn. But in case of a single male parent, the same could be true of father even though there is no concept of father's tongue. This type of culture-specific notion was however seen totally as a misnomer by certain critics of the notion itself. ${ }^{\mathrm{v}}$ The first language of a child is part of their personal, social and cultural identity. Another impact of the first language is that it brings about the reflection and learning of successful social patterns of acting and speaking. It is basically responsible for differentiating the linguistic competence of acting. ${ }^{\text {vi }}$ The linguists as well as educational technologists feel mother tongue is a "blessing in disguise" for people. ${ }^{\text {vii }}$ This is because it is not merely a time-table subject in his education but is forced upon him from all sides. As a consequence it is learned by both the direct or conscious and the indirect or unconscious method. The direct method supplements and regulates the knowledge gained by hearing. The mother tongue is hence an instrument for the development of the intellectual, moral and physical aspects of education. ${ }^{\text {viii }}$

Historically the term was used by Catholic monks to designate a particular language they used, instead of Latin, when they were "speaking from the pulpit." ${ }^{\text {.ix }}$ That is, the "holy mother of the Church" introduced this term and colonies inherited it from the Christianity as a part of their colonial legacy, thanks to the effort made by foreign missionaries in the transitional period of switching over from 18th C. Mercantile Capitalism to 19th C. Industrial Capitalism in India. ${ }^{\mathrm{x}}$ In many countries such as Kenya, India, and various East Asian countries, "mother language" or "native language" used to indicate the language of one's ethnic group, in both common and journalistic parlance rather than one's first language. ${ }^{\text {xi }}$ In Singapore, "mother tongue" refers to the language of one's ethnic group regardless of actual proficiency, while the "first language" refers to the English language 
that was established on the island through British colonization, which is the lingua franca for most postindependence Singaporeans due to its use as the language of instruction in government schools and as a working language. ${ }^{\text {xii }}$ J. R. R. Tolkien in his 1955 lecture "English and Welsh" distinguished the "native tongue" from the "cradle tongue," the latter being the language one happens to learn during early childhood, while one's true "native tongue" may be different, possibly determined by an inherited linguistic taste, and may later in life be discovered by a strong emotional affinity to a specific dialect.

The Brazilian linguist Cleo Altenhofen considered the denomination "mother tongue" in its general usage to be imprecise and subject to various interpretations that are biased linguistically, especially with respect to bilingual children from ethnic minority groups. He cites his own experience as a bilingual speaker of Portuguese and Riograndenser Hunsrückisch, a German-rooted language brought to southern Brazil by the first German immigrants. In his case, like that of many children whose home language differs from the language of the environment (the 'official' language), it is debatable which language is one's 'mother tongue'. Many scholars have given definitions of 'mother tongue' through the years based on common usage, the emotional relation of the speaker towards the language, and even its dominance in relation to the environment. However, all of these criteria lack precision.

The mother tongue was therefore defined variously,

- Based on origin: the language(s) one learned first (the language(s) in which one has established the first long-lasting verbal contacts).

- Based on internal identification: the language(s) one identifies with/as a speaker of;

- Based on external identification: the language(s) one is identified with/as a speaker of, by others.

- Based on competence: the language(s) one knows best.

- Based on function: the language(s) one uses most.

Although the word mother tongue essentially means a language learnt from the mother it gradually developed into a concept wherein mother tongue began to imply language of the community, nationality or the nation. In other words in certain interesting cases of an inter nationality marriage, if the mother belongs to a language group who did not speak the language of the father's nationality, still the off spring's mother tongue would be the language of the land i.e of the father's nationality. Although it is called mother tongue it has therefore serious patriarchal implications. The concept of mother tongue is based on the concept of mother/father land. The concept of mother tongue is of European origin. In the sixteenth century when the clergymen standing on their 'Holy Alter' delivered speech or sermonized in any language other than Latin, it was called the mother tongue of mother church (e.g. Mother of God-virgin Marry). ${ }^{\text {xii }}$ This mother tongue was therefore the vernacular. Ivan Illich has shown that the word had entered the Indian Territory only in $18^{\text {th }}$ century. ${ }^{\text {xiv }}$

\section{Historical Perspective of the Bengali Language}

In 1837 the British Government announced that all administrative communication under the rule of East Indian Company must be done in vernacular. The Fort William College was established to train the administrative officers in vernacular. In the Fort William College William Carry edited the specimen book entitled 'Kothopokothan' (Art of Conversation) to teach Bengali to the job seekers aspiring employment as clerks in the offices of the East India Company. This "Kothopokothan" remained a significant example of Bengali prose in the history of Bengali literature. The metaphysical structure of Bengali language and literature continued to grow centering round this college. But the Bengali prose that was being produced by the Sanskrit scholars to facilitate the trade and commerce of their 'colonial masters' was not successful because it was not really conversational language of the Bengali language of the then Bengal. It was actually a kind of Bengali prose which was heavily Sanskritised and hence incomprehensible to the commoners. For this reason sufficient Arabic and Persian words were included in the First edition of 'Kothopokothan'. In the second edition it was found that Arabic and Persian word were replaced by Sanskrit words. ${ }^{\mathrm{xv}}$

The Bengali language that emerged was thus a result of the collaboration of the English masters and Bengali subjects. This has been confirmed by a colonial grammarian himself. In 1872 John Beams said, "The Bengali language originally a rule off -School of Magadhi-Prakrit has within the present century been much cultivated and enriches by revival of Sanskrit words. Many excellent books have also been written in it." ${ }^{\text {"xi }}$ A critic feels that the development of Bengali language not only was a result of master-subject collaboration in Bengal but actually an imitation of the master by the subject in shaping his language. Thus the Bengalis prepared the language according to the requirement of their masters. Hence the trajectory of the Bengali language follows the trajectory of the English language. ${ }^{\text {xii }}$ The master had developed the idea of mother tongue in Europe, so the subject also has developed the concept of mother tongue. The master had the idea of nation which he had derived from the idea of mother tongue. The subject also had formed the idea of a nation from the idea of mother tongue. The masters might write from any province of England but they write in the same language and the subject also prepared one standard language instead of many dialects so that all conversation 
Impact of Language on National Identity: An Analysis from Historical Perspective.

related to trade and commerce could be conducted. To keep pace in every field the subject also required a historical base for his language, literature and nationhood like that of his master. Hence a history of the Bengali people was sought to be constructed. It was this need that made Bankim Chandra Chattapadhaya write, "Bengali requires a history, otherwise the Bengali will never become complete man" and this will not be like kerry's 'Kothopokothan' rather it must be like history of Bengal written by Marshman and translated as 'Bangalar Itihas' by Vidyasagar even before this subject started to write history. ${ }^{\text {xiii }}$ In 1869 Harimohan Mukhopadhay wrote 'Kobicharit', in 1871 and in the same year Mahendra Nath Chottopadhay wrote 'Bongobashar Itihas' and in between 1872 and 1873 Ramgathi Nayaratna wrote 'Bangla Bhasha and Bangla Sahitya Bishayak Prastab', Raj Narayan Bose wrote 'Bangla Bhasa O Sahitya Bishayak Bakrita' in 1876, 'Literature of Bengal' by Ramaesh Chandra Dutta in 1877 and Dinesh Chandra Sen made this sequence more strong by writing his important book, 'Bongo Basha o Sahitya' ${ }^{\text {xix }}$ The construction of a rich past was necessary to write a write history of its own self without which an appropriate nation building was not be possible. The subject would not have equal status of his master without similar proud history. Therefore even when they have a text like 'Charyacharyabinischoy' they needed the approval of the colonial rulers that its language was indeed Bengali. But other subject contested this by the same logic. So Gopal Chandra Praharaj claimed that the language of 'Charyacharyabinischoy' was written in old Orya language. Rahul Sanskrittayan or Kali Prasad Jaiswal asserted that its language was Magadhi (A dialect of Bihari group) while Bani Kanta Kakati felt that it was written in Assamese. Shibnandan Tagore or Subhadra Jha was sanguine that it was ancient Maithili language and Kanaklal Boruah felt that this was an example of mixed form 'Maithili Kamrupi' language.

Language question cannot be isolated from overall nationality question. ${ }^{\mathrm{xx}}$ In all the definition of nationhood, language has been seen as an integral component. ${ }^{\mathrm{xxi}}$ The other important component was territory. As nationalist discourse emerged as one of the most powerful discourses of modern world, territory was feminized and deified as mother land. Since then national territory did not remain a simple piece of land in this discourse, it became a sacred territory known as mother land and the language spoken by the inhabitants of that territory was seen as mother language. Although it is not known whether mother land was the precursor of mother language and vice versa, the organic relationship between the two was apparent. Thus nationhood involves the presence both of motherland as well as mother tongue. Although in the post modern times the importance of both has been questioned, they had not lost their political relevance. What is ironical is that in a territory there was generally not one mother tongue. There is hardly a habitat which comprises of only one group of people. Most areas are plural and have speakers of multiple languages. Thus while mother tongue of the majority develops as dominant language of the area, others were suppressed. Therefore a mother tongue of a majority can be the carrier of Chauvinism and at the same time oppressor of minority language. ${ }^{\text {xxii }}$ Motherland would apply to the majority community who might object to the territorial rights of the other minority inhabitant of this same land. But the minority communities then used the same discourse and appropriate the concept of mother tongue and mother land for their land and land right and nationality right. The concept of mother tongue and mother land was immortalized in Bengal and later in India by Bankim Chandra Chatterjee in the song "Bande Mataram" Similarly the concept of mother tongue was recognized and institutionalized by declaring $21^{\text {st }}$ Feb as International mother Tongue by UNESCO on 17 November 1999, ${ }^{\text {xxiii }}$ the day youths lost their lives in East Pakistan fighting for their mother tongue.

\section{Language Movement in Barak Valley of Assam}

As far as Barak valley is concerned it consists currently of three districts - Cachar, karimganj and Hailakandi. Earlier they all formed only one district called Cachar district of Assam. Karimganj became a part of Assam only in 1947. Cachar including Hailakandi was the habitat of diverse tribal and ethnic groups. Hailakandi is overwhelmingly Muslim, surrounded by a number of tribal groups. While the Hindus and Muslim spoke a dialect of Bengali language known as Cachari-Sylheti, ${ }^{\text {xiv }}$ the tribal spoke a myriad variety of IndoBurman languages. Similarly Cachar was the kingdom of the Dimasa rulers with Khaspur as their capital. This too is a largely multi ethnic region. Besides the Dimasa who spoke their Dimasa language, there was a large number indigenous Muslim population who constituted the functionaries and armed forces as well as revenue officials of the kingdom. A small number of Bengali Hindus comprise the priestly classes, all of whom spoke a dialect know as 'Sylheti' or 'Cachari', one of the dialects of the large Bengali language. Among the other indigenous population were the Naga, Chorai, Rangkhal, Khasi, Dimasa, riang, Muolansom, Garo, Chakma, Biata, Mizo, Imol, Karbi, Chiru, Ranglong, Halom, sakachep, Tripura, Jayantia, uchodi, Rupini, Rajbanshi, Rangkhong, Kuki, and Kmar. During the Burmese invasion of Manipur and Assam a large number Meithei, Bisnupriya, Rongmei, and Koch communities migrated and settled in Cachar. From 1856 tea began to be grown in Barak Valley. With the development of tea as an Industry a massive number of tea labour population were recruited through an indentured labour system were brought and settled in the tea gardens. These immigrants were from different tribal areas of Bengal, Bihar, Orissa, Uttar Pradesh, Madhya Pradesh, and even from South Indian provinces speaking diverse speeches. A small number Bengali Hindus were also settled as the managerial 
Impact of Language on National Identity: An Analysis from Historical Perspective.

functionaries of the tea garden. The partition of India in 1947 witnessed massive number of displaced Bengali Hindus immediately emerged as the numerical majority in Cachar District. Though Cachar district was plural and multi linguistic, the numerical strength of the Bengali Hindus was able to establish the dominance of Bengali language. The Dimasa kings of the Cachar state were patrons of Bengali language and culture. They had already popularized Bengali language and often used it as the Lingua Franca of the people. Since Bengali was already an established language of this state, the dominance of Bengali language was only a matter of time. In the urban areas Bengali emerged as the medium of interaction of the people as well as of un-official instruction. Therefore when the resistance to the imposition of Assamese language was launched as a struggle for the survival of the mother tongue, there was no immediate opposition to it. But as the movement was analyzed in retrospect the non-inclusion of other language groups had become visible. There was a tacit withdrawal of support by the tea garden and tribal language groups. It made the features of the movement evident. The Hailakandi incident of $19^{\text {th }}$ June, 1961, when a group of Bengali speaking Muslims voiced against the Bengali language movement and attacked the supporters of Bengali Language that caused killings of some protesters by police firing, was an example of the dominance of a particular religious-language group. No wonder the Hailakandi episode marked the temporary end of the so called "Bhasha Andoolon" (Language movement).

\section{Conclusion}

In all the language movements martyrdom is making unique by calling it language martyrs. This is because martyrdom is associated generally with religion on political cause. Martyrdom for a cultural marker is less and infrequent hence language was associated with mother and thereby endowed with the necessary emotions that associated with mother. Fight for mother tongue is, therefore, not just a struggle for reinstatement of the respective vernacular but a resistance to persecution to a symbol (language) which is associated with the 'mother' of the community.

\section{References}

[1]. The Concise Oxford Dictionary, 9th edition, Oxford university press Delhi edition, 1996

[2]. Retrieved from "http://en.wikipedia.org/w/index.php?title=First_language\&oldid=517421623

[3]. Santanu Sarkar, Adhipatya O Bangla Bhasha, (Hegemony and Bangla Language), in Bengali, Occasional paper no.6, Department of Bengali, Assam University, Silchar, 2007

[4]. Prakash Karat Language and Nationality Politics (Orient Longman, Hyderabad)

[5]. J V Stalin, Marxism and National Question, in Selections from Lenin and Stalin on National Colonial Questions, Calcutta, 1972

[6]. Koffi Annan's Letter announcing the celebration of 21 st February as mother tongue day

[7]. Jagannath Chakraborty, Lexicon and Linguistics of Dialectical Language of Barak Valley, Language and Cultural Academy Assam, Halflong, 1412 B.

[8]. Baldeva Sahani, President, The Bihar Association, A Memorendum Presented to the State Reorganisation Commission.

[9]. Doccuments of Bangladesh Liberation War, 15 Vols., Published by the Ministry of Bangladesh Liberation War, Govt. of Bangladesh, (Reprint 2004)

[10]. C. A. Grierson, Linguistic Survey of India, Vol. I, Part I, Delhi, 1967

[11]. M. Z. Abbasi, 50 Years of Ekushe February Celebrating the Mother tongue, Bangladesh Shilpokala Academy, 2002.

[12]. Sandhya Goswai, Language Politics in Assam, Delhi,1997.

[13]. Sajal,Nag, Roots of Ethnic Conflict: Nationality Questions in North East India, Delhi, Manohar, 1990.

[14]. Subir Kar, Barak Upatyakar Bhasa Sangramer Itihas, Pustak Biponi, Kolkata, 1999.

[15]. D. K. Laskar, (ed), Unisher Bhasa Shahidera,(Language Martyrs of 19th), 7 vols., Lalon Mancha ,Karimganj, 2002.

\footnotetext{
${ }^{\text {i }}$ The Concise Oxford Dictionary, $9^{\text {th }}$ edition, Oxford university press Delhi edition, 1996, p.887

ii Retrieved from "http://en.wikipedia.org/w/index.php?title=First_language\&oldid=517421623"

${ }^{\text {iii }}$ Retrieved from "http://en.wikipedia.org/w/index.php?title=First_language\&oldid=517421623

${ }^{\text {iv }}$ Retrieved from "http://en.wikipedia.org/w/index.php?title=First_language\&oldid=517421623

${ }^{v}$ Retrieved from "http://en.wikipedia.org/w/index.php?title=First_language\&oldid=517421623

${ }^{\text {vi }}$ Retrieved from "http://en.wikipedia.org/w/index.php?title=First_language\&oldid=517421623

${ }^{v i i}$ Retrieved from "http://en.wikipedia.org/w/index.php?title=First_language\&oldid=517421623

viii Retrieved from "http://en.wikipedia.org/w/index.php?title=First_language\&oldid=517421623
}

${ }^{\text {ix }}$ Santanu Sarkar, Adhipatya O Bangla Bhasha, (Hegemony and Bangla Language), in Bengali, Occasional paper no.6, Department of Bengali, Assam University, Silchar, 2007, p14; Retrieved from

"http://en.wikipedia.org/w/index.php?title=First language\&oldid=517421623

${ }^{x}$ Retrieved from "http://en.wikipedia.org/w/index.php?title=First_language\&oldid=517421623 
${ }^{x i}$ Retrieved from "http://en.wikipedia.org/w/index.php?title=First_language\&oldid=517421623

${ }^{x i i}$ Retrieved from "http://en.wikipedia.org/w/index.php?title=First_language\&oldid=517421623

xiii Santanu Sarkar, Adhipatya O Bangla Bhasha, (Hegemony and Bangla Language), in Bengali, Occasional paper no.6, Department of Bengali, Assam University, Silchar, 2007, p14

${ }^{\text {xiv }}$ ibid

${ }^{\mathrm{xv}}$ ibid

${ }^{\text {xvi }}$ Ibid, p. 15

xvii ibid

xviii ibid

xix Ibid, pp. 15-16

${ }^{\mathrm{xx}}$ Karat Prakash, Language and Nationality Politics, Orient Longman, Hyderabad, p.1

${ }^{x x i}$ For example J V Stalin, 'Marxism and National Question,' in Selections from Lenin and Stalin on National Colonial Questions, (Calcutta, 1972, pp.66-72

xxii Santanu Sarkar, op.cit

xxiii Koffi Annan's Letter announcing the celebration of $21^{\text {st }}$ February as mother tongue day

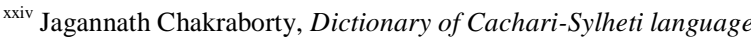

